\title{
Secure Electronic Payment: Proposed method for the growth of E-commerce in Bangladesh
}

\author{
Md. Monirul Islam', Harunur Rashid ${ }^{2}$, Md. Golam Rabiul Alam ${ }^{3}$ \\ ${ }^{1,3}$ Associate Professor, Department of Computer Science \& Engineering, International Islamic University Chittagong, BANGLADESH \\ ${ }^{2}$ Professor, Department of Accounting and Information Systems, University of Chittagong, BANGLADESH
}

\begin{abstract}
The innovations in technologies are changing the social, cultural and economic relationships in a vast variety of ways. Information technology has become a necessary tool for today's organizations and banking industry is not an exception. Electronic commerce is rapidly growing modern business process in all over the world, but in Bangladesh it is increasing comparatively slower rate. Though Bangladesh was comparatively a late introducer of e-banking but now almost all the banks are providing internet banking to their customers. But what is important is the lack of comprehensive study of the e-payment security covering organizational and customers' point of view. Considering the importance of secure e-payment to grow up e-commerce in Bangladesh this study was taken up. It was revealed from the survey that the customers' and service providers main concern was security. E-banking service providers should have to ensure that online banking is safe and secure for every user in all kind of transactions. The Authors also proposed a secure e-payment model in general and on debit card and credit card to bring customers confidence on e-payment and increase the volume of e-commerce in the context of Bangladesh.
\end{abstract}

Keywords: E-payment, Credit Card, Debit Card, Security, E-commerce

\section{INTRODUCTION}

Until 2009, the banking system in Bangladesh had been following a paper based route. After that, most of the private commercial bank with the supportive role of Bangladesh Bank, the country moved towards an automated banking system that is compatible with international standards. In Bangladesh, e-banking provides various services like online banking, debit card, and credit card services, ATM services, home banking, internet banking, telebanking, mobile banking, etc. Though many different ebanking channels are in practice, in this paper author has concentrated on e-payment, particularly through debit and credit card. Cyber laws are not really in well practiced; as a consequence internet banking users do not feel secure. In the course of the study some challenges were also identified in adaptation and operation of the internet banking in Bangladesh. E-commerce is mainly dependent on the Internet and the access, pricing, and secure e-payment that can bring confidence to the customers. The major challenges of e-commerce is the secure e-payment in Bangladesh identified are i) weak organizational and policy matters, ii) inadequate infrastructure, iii) lack of security, safety and secrecy, iv) weak awareness service and v) weak legal framework. As to the challenges, the study stresses that ebanking requires skilled, trained people in one hand and motivational and policy support from top management and policy makers on the other. Security is a major concern and challenge of e-payment adoption in Bangladesh. Banking is highly regulated business but in the context of e-payment in Bangladesh, adequate legal framework, policy directions are found lacking. Customers perceive that security, awareness, quality of internet connection, trust and privacy is in a poor condition. Thus, challenges need to be identified, addressed timely so that in the global arena in e-business and ebanking Bangladesh can be one of the leading partners.

\section{LITERATURE REVIEW}

Commerce through the Internet is the e-commerce. Ecommerce has defined as "the use of electronic transmission mediums to engage in the exchange, including buying and selling, of products and services" Marilyn Greenstein et al, (2002).

Nitai Chandra Debnath (2007), says the banking mechanism plays a pivotal role in the settlement of the etransactions. Banking mechanism refers to the automation of operation, convertibility of currency, credit / debit cards etc. An off-line computerized reconciliation and data management system has been implemented by the Central Bank of Bangladesh for the settlements of inter bank transactions or clearing house. Some bankers given their opinion regarding e-payment in Bangladesh in a seminar, Daily Star, (March 8, 2015), Hassan Zaman, Chief Economist, Bangladesh Bank, says from the macro point of view, the facilitation of ecommerce is good for growth, particularly for service sector related growth. We are concerned about security. A M M Moyen Uddin, Head of IT, Eastern Bank Ltd., says in Bangladesh, there are some challenges to maintaining a secure electronic payment system. SIM replacement is one of the big challenges. Anyone can withdraw anyone's SIM. Some banks send OTP (One Time 
Password) through SMS. But anyone can get the OTP by replacing the SIM. A N MN Nurul Haque, Ex-Banker, said that electric banking is more secure. But a private sector bank experienced a major fault in credit card where 21 credit cards were used for forging about 100 million taka. Similar thing happened with another private and one public sector bank. Some banks are charging a high amount of service charge in the name of electronic banking. It is not friendly to poor clients.

In India Kaur, Jasveen and Kaur, Baljit, (2013) in a study shows that there is no significant difference in facilities determining the customers' usage of internet banking services of Public-sector, Private-sector and Foreign Banks in India.

In Malaysia Hari Mohan (2013), conducted a study and used Technology Acceptance Model (TAM) and considered factors were performance expectancy, effort expectancy, social influence, facilitating condition, trust, behavioral intentions. The study showed that selfefficiency and trust are not related positively with the intention towards online banking while perceived ease of use influences the intention towards online banking.

Chibueze (2013) in Nigeria showed that electronic banking has improved returns on the equity of Nigerian banks. The study revealed that the adoption of electronic banking has positively and significantly improved the returns on equity (ROE) of Nigerian banks. On the other hand, it also revealed that internet banking has not significantly improved the returns on assets (ROA) of Nigerian banks.

Irteza Hoque (2012) made an analysis of the customer satisfaction of internet banking in Bangladesh with a focus on Citibank N.A. The study shows that around $70 \%$ users have a positive attitude towards internet banking.

Rahman, (2012) pointed out that e-banking has become a necessity for banks. It offers the major opportunities in terms of competitive advantages and operational effectiveness within the company and develops a stronger and more durable business relationship with its customers. Yang Jing (2009) says the on-line electronic payment is the electronic commerce development core. In the electronic commerce practice, the online electronic payment is the electronic commerce essential link, also is the foundation condition which electronic commerce can smoothly develop.

Chian Son Yu (2012) in a study in Taiwan cited that fast advances in the wireless technology and the intensive penetration of cell phones have motivated banks to spend large budget on building mobile banking systems, but the adoption rate of mobile banking is still underused than expected.

Bahl Sarita, (2012) in a work in India determined that security and privacy issues are the big factors in ebanking. If security and privacy issues are resolved, the future of electronic banking can be very prosperous.
Singh (2012) conducted a study in Singapore and mentioned that Singapore is known as the fastest growing telecommunications nation in Asia. The result shows that customer attitude (CA), perceived usefulness (PU) and perceived ease of use (PEOU) are critical factors that affect the user acceptance.

Mihir Kumar Roy (2011) mentioned in a research that the study investigates into online banking acceptance in the light of the traditional technology acceptance model (TAM), which is leveraged into online environment. The main findings are the perceived ease of use, security and privacy, and online information are significantly correlated with online banking uses of the customers.

Sohel Ahmed (2011) in a study found out the problems and prospects of mobile banking in Bangladesh. As to adoption, about $55 \%$ people feel they should use it and $45 \%$ people don't feel to use mobile banking according to the survey.

Hasan (2010) conducted an exploratory research and it finds that as a developing country, Bangladesh is far behind to reach the expected level in global banking system. The results showed that e-banking provides several advantages to Bangladeshi banking sector. This study also observed that the Bangladeshi customers do not have enough knowledge regarding e-banking which is rendered by banking sector in Bangladesh.

Jannatul Mawa Nupur (2010) conducted a study concentrating on e-banking and customers' satisfaction in Bangladesh. The result of the study showed that customers' satisfaction on e-banking is above satisfactory level (with a mean value of 3.93 on a 5 point Likert scale). The customers are less satisfied on equipment, physical facilities, appealing materials, etc.

Razibul Hasan et al (2012) mentioned that currently eCommerce system security focuses on mechanisms such as secure transactional protocols, cryptographic schemes, parameter sanitization and it is assumed that putting these in place will guarantee a secure e-Commerce application.

From the aforesaid literature review and evaluation of ebanking in developed and developing countries and in Bangladesh, it is evident that internet use and e-banking studies were conducted in different dimension and that sound and secure e-banking only can be achieved if a country can ensure good infrastructure and manpower. The study seeks to evaluate different aspect of the ebanking from structural, regulatory aspect, present status, aspects relevant to users, types of services provided, legal aspects, current practices, challenges and security issues etc.

\section{ObJectives OF THE Study}

The prime objective of this study plans to identify the problems of e-payment and proposed a possible solution of e-payment for the growth of e-commerce in Bangladesh. In such a perspective the specific objectives of this study are: 
- To evaluate the customers and bankers perception towards e-payment in Bangladesh.

- To evaluate the present e-payment systems and also identify the problems in current practices.

- To provide a model of secure e-payment in general point of view.

- To provide a model of secure e-payment through debit or credit card in Bangladesh.

\section{Research Design and Methodology}

It is to be mentioned that in this study both qualitative and quantitative research approach were applied. Information collected from primary and secondary sources have been used to (i) assess the theory, practice and problems of internet banking (ii) analyze the status, problems and prospect of internet banking and e-payment practiced in Bangladesh and (iii) provide insight for policy formulation for e-payment in Bangladesh.

\section{Sample Size}

Internet banking respondents have been selected from a total of 25 banks in Bangladesh. The banks were selected randomly from the list of three types of banks, i.e. private commercial banks, public commercial banks and foreign commercial banks. Out of those 25 banks, 20 were from private commercial banks, 3 from state owned commercial banks and 2 from foreign commercial banks. As to selection of banker respondents i.e. internet banking service provider, have been selected at random totaling 50 respondents taking 2 respondents (one Manager and another IT Professional) from each bank. Internet banking users' respondents i.e. banks clients have been selected at random totaling 250 respondents taking 10 respondents from each bank. The period of survey was in January 2014 in Chittagong and Dhaka.

\section{Implications and Policy Recommendations}

The study revealed a number of flaws in the arena of ebanking with reference to security and safety especially in the context of E-payment, secured payment through credit card and organizational and legal framework. Against these major flaws a general model of secure epayment and also proposed model for debit and credit card payment and some recommendations are offered to minimize the flaws and overcome the shortcomings.

\section{Proposed Secure E-Payment Model for BANGLADESH}

Security is the main concern and a vital issue for the success of e-banking. As the security concern warrant top most importance it is proposed that WAP/GPRS (Wireless Application Protocol/General Packet Radio Service) based collaborative e-payment model developed by Sazzad et al (2011) is worth consideration for ebanking in Bangladesh. In this model central bank, local banks and mobile operators are involved in payment processes. The proposed model is shown in Figure 1.

Figure 1: Proposed Model for Secure E-payment in Bangladesh

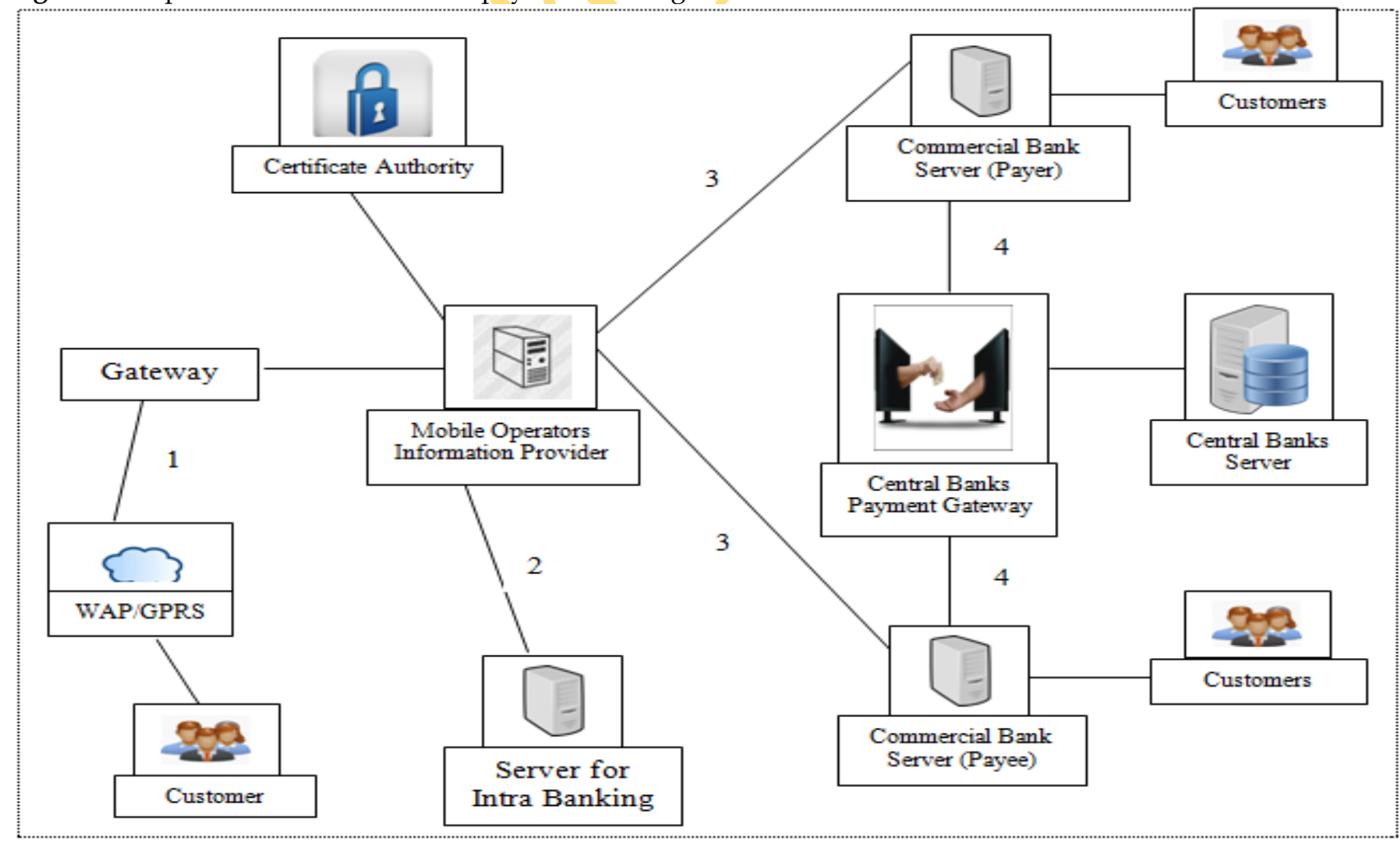

Source: Proposed e-payment model 
The certification authority provides license to the mobile operators for providing e-banking services. The banks who are interested to facilitate their customers in ebanking facility should resister with the mobile operators. The central bank should have full control over the local banks monitory transaction and each local bank has to maintain an account on central bank. The customers who are interested to get e-banking services will have to register with mobile operators through cell phone wallet as advocated by Shifeng L. et. al (2010). At the time of registration the customers are suppose to provide all the available bank accounts s/he holds and wants to transact money through e-banking. After registration the mobile operator will provide a unique personal identification number (PIN) which acts as a secret key of monitory transaction. So, using the epayment, customers can use multi-home with several debit and credit payment instruments in a single wallet and customer can handle several bank accounts with the single pin code $\mathrm{s} /$ he received from mobile operator. It can be used for both intra and inter banking transactions. In the proposed model, sequence 1 and 2 will be followed for intra banking transactions and sequence 1, 3 and 4 will be followed for inter-banking transactions.

\section{Level of Security Analysis of Model}

In this model, connection between mobile user (registered ebanking customer) and mobile operator's content provider is wireless connection. And connection among payer and payee bank server, central bank server and mobile operator's content server is wired connection. Wireless connection is most vulnerable to e-banking security attacks. Most of the existing WAP based e-banking architecture uses WAP specification and wireless public key infrastructure (WPKI). WAP protocol architecture consists of WTLS (Wireless Transport Layer Security) protocol and WAP Identity Module (WIM) which is used to store user's certificate and SignText function that allows the WAP signage in transaction.

a) Image Steganography: Beyond the WAP security we propose to use image steganography to ensure security of pin code and account information of registered epayment users. Steganography literally means, "covered writing" and encompasses methods of transmitting secret messages through innocuous cover carriers in such a manner that the existence of the embedded messages is undetectable, Hasan M. M (2005). To maximize the embedding capacity of each pixel we propose to use adaptive encoding using 4th LSB insertion method. The basic steps of implementing adaptive encoding method are calculating insertion bits among pixel, minimum error replacement and error diffusion. The imperceptibility and data encryption capability of adaptive encoding method is very high and it is robust against statistical attacks. Bit error rate (BER) is also decreasing in this method because of using 4th level LSB (least significant bit) insertion method, which ensures data integrity. b) Biometric Authentication: Client authentication is very much important issue of e-banking architecture. We propose to use biometric authentication mechanism through fingerprint biometric. In our proposed approach, we don't want to store fingerprint image on phone, the m-wallet has the option to capture and process fingerprint in run time. Then hash the fingerprint to ensure that the intruder will not able to capture it in its raw form. We implement the fingerprint mechanism for java enabled platform using MIDP (Mobile Information Device Profile) forms that supports CLDC (Connected Limited Device Configuration). During the process of account opening in a bank, the client will be offered the fingerprint biometric authentication. The fingerprint biometric of each and every client will be stored in the bank's server to authenticate clients of ebanking services.

\section{Services and Steps of Proposed Model}

The different services and steps relevant to the use of proposed secure e-payment systems are discussed below:

a) Registration: Registration is the process to collect information and authenticate person interested to be ebanking customers. Registration shall have to be made mandatory for all the stakeholders of e-banking services. A customer will register for his multiple bank accounts in a similar bank and also will be allowed to register for his bank accounts in different banks with a single mobile number. It will not be allowed to use the same cell phone number for registering of two different customers. A unique PIN number be assigned and provided to each of the registered e-banking customer, which will not be shared and should be kept secret. Biometric fingerprint will also be necessary to complete the registration process, which will be used for unique identification of customers and to avoid nonrepudiation. The summary of the registration procedure is shown in Table 1.

Table 1: Summary of Representation of Registration

Services

Step 1 Registration: E-Banking, Manual Banking

Step 2 E-Banking: E-payment

Step 3 Registration Mobile Number, Title of Bank Account, Information: Account Number, Finger Print.

Step 4 Registration Confirmed Registration and Provide PIN or Status: Registration Unsuccessful

b) Intra-bank Fund Transfer: Fund transfer between the account holders of the same bank (different or same branch) is called intra-bank balance transfer. To get this service, the payer and payee should be a registered customer of e-banking service. Payer account holder should provide his account number, payee's account number, his secured PIN number, amount to be transferred and his fingerprint. Authentication of payer will be verified at his home branch. After checking available balance and transferring requested amount from payer's account to payee's account, bank's local 
server will send acknowledgment to bank's central server. Then banks central server will send acknowledgement to both the payer and payee's mobile number. The summary of intra bank balance transfer procedure is shown in Table 2.

Table 2: Summary of Representation of Intra Banking Services

\begin{tabular}{|c|c|c|}
\hline$\overline{\text { Step } 1}$ & Balance & Correct Selection, Wrong Selection \\
\hline & Transfer Menu & \\
\hline Step 2 & $\begin{array}{l}\text { Balance } \\
\text { Transfer Type }\end{array}$ & Intra-banking, Inter Banking \\
\hline Step 3 & $\begin{array}{l}\text { Balance } \\
\text { Transfer } \\
\text { Information }\end{array}$ & $\begin{array}{l}\text { Payees Account Number, Transfer Amount, } \\
\text { Security PIN, Finger Print. }\end{array}$ \\
\hline Step 4 & $\begin{array}{l}\text { Balance } \\
\text { Transfer } \\
\text { Status: }\end{array}$ & $\begin{array}{l}\text { Successful with Balance Transfer } \\
\text { Acknowledgement, Unsuccessful with Error } \\
\text { Message. }\end{array}$ \\
\hline
\end{tabular}

c) Inter-bank Fund Transfer: Inter-bank fund transfer is another imperative service of e-banking. Balance transfer among the account holders of different banks is called inter-bank balance transfer. Countries national payment gateway and central bank server are responsible for transactions among different banks.

Generally each and every bank maintains an account at the central bank (Bangladesh Bank). Payer account holder should provide his account number, payee's account number, his secured PIN number, amount to be transferred and his fingerprint. Mobile operator's content provider will send necessary information directly to the payer and payee bank's central server. Authentication of payer and payee will be verified at his home branch. After authentication of payer and checking available balance, acknowledgement will be sent to the central banks server. Existence of payee's account will also be verified at the payee's home bank branch and the acknowledgement will be sent to the central bank's server from local bank's server. The central bank will transfer balance from payer bank account to payee bank account.

Table 3: Summary of Representation of Interbank Services Step 1 Balance Transfer Correct Selection, Wrong Selection Menu

Step 2 Balance Transfer Intra Banking, Inter-banking Type

Step 3 Balance Transfer Payees Account Number and Bank Name, Information Payers Account Number and Bank Name, Transfer Amount, Security PIN, Finger Print.

Step 4 Balance Transfer Successful with Balance Transfer Status: Acknowledgement, Unsuccessful with Error Message.

After successful balance transfer local bank's central server will send an acknowledgement to both the payer and payee's mobile number. The summary of inter bank balance transfer procedure is shown in Table 3. d) Utility Bill Pay: Utility bill payment is one kind of micropayment system. The organization which provides utility services like electricity, gas, water, telephone and generator should have a utility bill account in a designated bank. Here, mobile operator acts as a third party to transfer balance from customers bank to utility bill receiver bank. As utility bills are micro-payment and both customers' bank and utility bill receiver bank should have a registration with the mobile operator, so there will be no need to use the national payment gateway. The summary of utility bill pay procedure is shown in Table 4.

Table 4: Summary of Representation of Utility Bill Pay Services

\begin{tabular}{lll}
\hline Step 1 & Bill Pay Menu & \multicolumn{3}{c}{ Correct Selection, Wrong Selection } \\
\hline Step 2 & Utility Bill & PayPayees Account Number and Bank \\
& Information & Name, Bill Pay Account Number, \\
& Amount of Bill, Security PIN, Finger \\
& Print \\
\hline Step 3 Bill Pay Status: & $\begin{array}{l}\text { Successful with Bill Paid Notification, } \\
\text { Unsuccessful with Error Message }\end{array}$ \\
\hline
\end{tabular}

\section{Structure of Payment through Credit and Debit CARD}

Figure 2 shows the current procedure of payment through credit card in Bangladesh and other countries. At the beginning of a transaction, a customer goes to the e-commerce web site using any web browser like Mozilla Firefox, Internet Explorer or Google Chrome by entering the address of the site in the address bar of the browser. When the user wants to confirm a transaction the ECommerce web site ask for his/her Credit card details such as Name, Card Number, Expire date, 3/4 digit secret number written back side of the card. If all the information asked is provided correctly then the transaction will be completed. Since all the transaction of credit card is account payee it is secure in certain level particularly in developed countries where commercial law and cyber law are in good practice.

Figure 2: Procedure of Payment through Credit and Debit Card

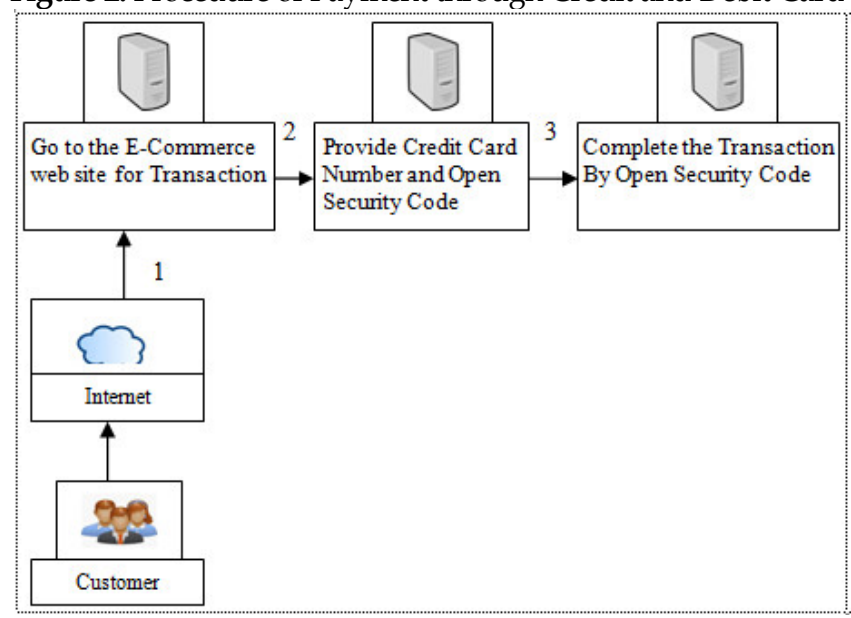

Source: Developed by observing current transaction procedure 
But in a country like Bangladesh, if anyone can use others' credit cards for transaction then it is very difficult to trace and get back money where business law and cyber law are not well established. A proposal is made for secure payment through credit card in the context of Bangladesh.

Proposed Model for Secure Payment through Credit Card in the Context of Bangladesh
To protect credit card transaction against breaches, the basic security architecture in credit card may include hidden PIN and One Time key (if required) along with appropriate firewalls and encryption. Since breaches of credit card payment may result in serious reputational damage or financial loss, the bank should seek as quickly as possible to allay the fears of customers. The Figure below shows the secure model for credit card in the context of Bangladesh.

Figure 3: Proposed Model for Secure Payment through Credit Card in Bangladesh

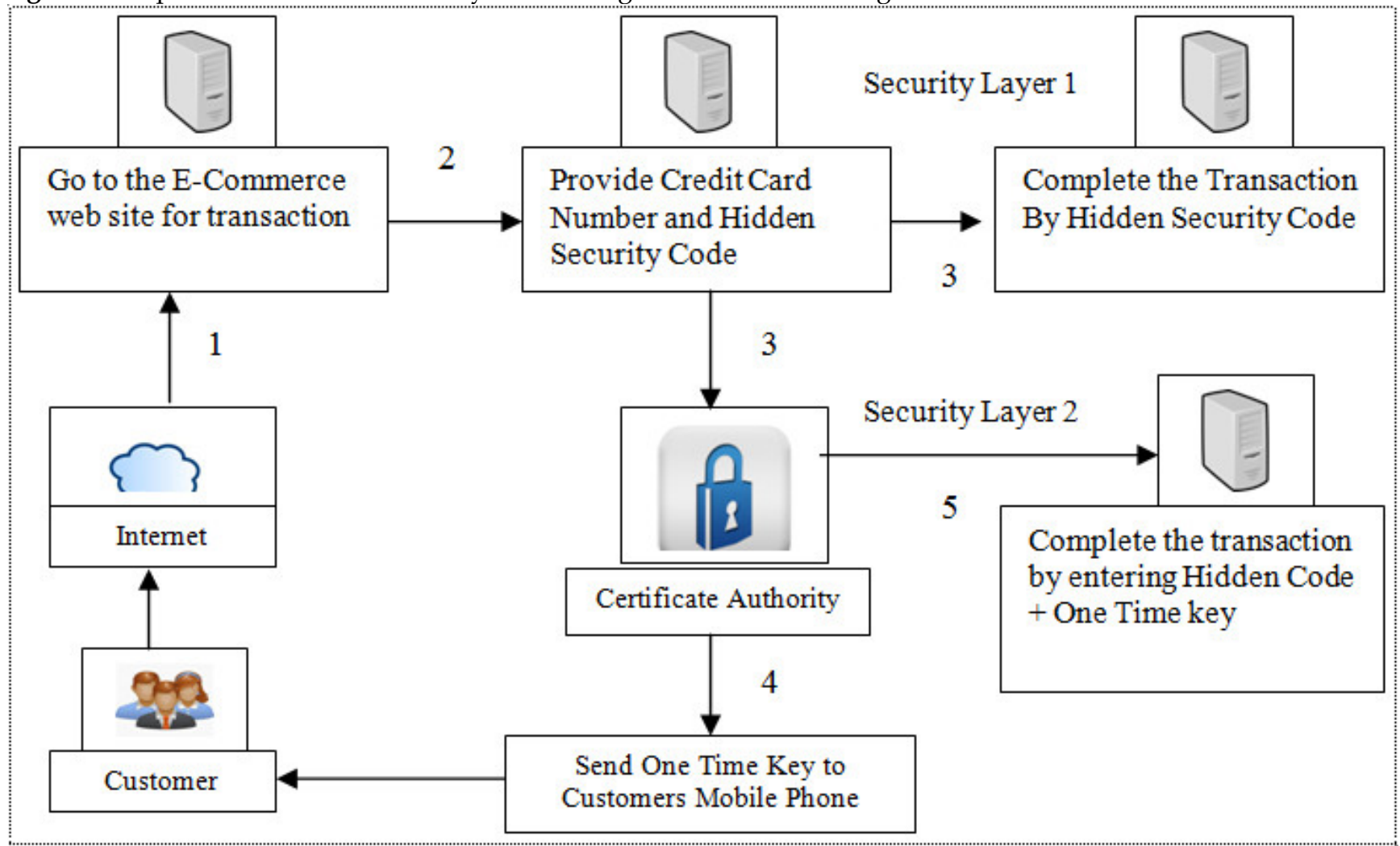

Source: Proposed e-payment model through debit and credit card

Description of the Proposed Security Model

Step 1: At the beginning of a transaction, a customer will go to the E-Commerce web site using any web browser like Mozilla Firefox, Internet Explorer or Google Chrome by entering the address of the site in the address bar of the browser.

Step 2: When the user wants to confirm a transaction the E-Commerce web site will ask for his/her Credit card details such as Name, Card Number, Expiry date, 3/4 digit secret number written back side of the card. If the user can enter the required information correctly, he/she will be taken to the step 3.

Step 3: Besides 3 digits open security code number Credit Card Issuing Banks/Institution can provide a secret PINs (personal identification numbers) to users to control access to credit card systems, and to ensure the integrity of passwords.
Step 4: A randomly generated one time password will be send to Customer's mobile phone. The ECommerce web site can collect the users' mobile number from the server of the credit card provider such as Visa or Master Card. The validity of the password will be 20 minutes. After entering one time password in the E-Commerce web site, the customer will click the $\mathrm{OK}$ button. Then the transaction will be completed.

If the proposed 2 layer security model can be used, then any fraud or hacking of password or any other security threat can be reduced. As this model is very simple, it can be implemented in Bangladesh without adding additional complexities to the E-Commerce System. Credit card issuing organization even can fix the level of security (Level 1 and 2) base on the amount of transaction. 


\section{CONCLUSION}

In order to make e-payment secure and make ecommerce effective in Bangladesh each of the operational and legal issues has to be addressed by the relevant authorities. Cyber law should be enacted to deal with fraud and settle any dispute between buyers and sellers. Electronic Fund Transfer being essential for giving necessary impetuous to e-commerce should be made secure and efficient. It is understood that the customers' main concern about any electronic payment is the security. E-banking service providers should have to ensure that online banking is safe and secure for every user in all kind of transactions. Bangladesh entered into internet banking since 2009 and showing a steady progress in this regard as to acceptance and operation of internet banking and e-payment. Banks should be designated and brought under licensing regime of certifying authority so that digital signature technologies based on Public Key Infrastructure may be introduced for increased security in EFT. Data Protection clause should be specifically introduced in the ICT Act along with defining sensitive personal data and manner and extent of their use by data controller such as Banks. Any kind of payment through debit and credit card must go through with one time key sent to the customers' mobile phone. Mobile SIM withdrawal must be stricken and may use biometrics security techniques. In fact in his global competitive and advanced technological development e-banking particularly e-payment in Bangladesh need to be well organized with safety, security, and customer satisfaction which may able to bring growth in e-commerce in Bangladesh.

\section{REFERENCES}

Bahl Sarita, "Emerging Challenges in E-Banking Upheavals in Global Scenario", Journal of Radix International Educational and Research Consortium, RIJEB Volume 1, Issue 7(July) ISSN: 2277-1018, 2012.

Chian Son $\mathrm{Yu}$, "Factors Affecting Individuals to Adopt Mobile Banking" Journal of Electronic Commerce Research, VOL13, NO 2, 2012.

Chibueze et al., "Electronic Banking and Bank Performance in Nigeria", West African Journal of Industrial $\mathcal{E}$ Academic Research, Vol.est 6 No.1 March, 2013.

Daily Star (2015), Electronic Payment System in Bangladesh: Pros And Cons, March 8, 2015, http://www.thedailystar.net/electronic-paymentsystem-in-bangladesh-pros-and-cons-26717

Hari Mohan, Norani Ahmad, Quah Chi Kong, Chiam Tzeh Yew , Jimmy Liew, Nik Kamariah Nik Mat, "Determinants of the Internet Banking Intention in Malaysia", American Journal of Economics, 3(3), pp.149152, 2013.

Hasan A. H. M. Saidul, Md. Azizul Baten, Anton Abdulbasah Kamil and Sanjida Parveen, "Adoption of E-banking in Bangladesh: An Exploratory Study",
African Journal of Business Management, Vol. 4(13), pp. 2718-2727, 4 October, 2010.

Hasan M. M., Alam M. G. R., Uddin M. I, Iqbal A. H. M. J. and Alam M. N., "A New Secret Key Steganographic Approach using LSB Hiding", International Conference on Computer and Information Technology, IUT, Gazipur, Bangladesh, pp. 859-863, 2005.

Irteza Hoque, "An Analysis of the Customer Satisfaction of Internet Banking in Bangladesh with a Focus on Citibank N.A", Independent University, Bangladesh. September, 2012.

Islam Md Monirul, "E-banking: Practices and Challenges in Bangladesh", Ph.D. thesis, University of Chittagong, Bangladesh, 2015.

Jannatul Mawa Nupur, "E-Banking and Customers' Satisfaction in Bangladesh: An Analysis", International Review of Business Research Papers, Volume 6. Number 4, pp. 145 - 156, September 2010.

Kaur Jasveen, KaurBaljit, “Determining Internet Banking Service Quality \& Customer Satisfaction in India shows", Tenth AIMS International Conference on Management, 2013.

Kothari, C.R., Research Methodology: Methods and Techniques, New Age International (P) Ltd., Publishers, India 2004

Marilyn Greenstein, Miklos Vasarhelyi, Electronic Commerce: Security, Risk Management, and Control with Power Web passcode card, Published by McGrawHill/Irwin (2002), ISBN 10: 0072519150, ISBN 13: 9780072519150

Mia, Md.Abdul Hannan, Rahman, Mohammad Anisur and Debnath, Nitai Chandra, "Consumer Behavior of Online Banking in Bangladesh", Journal of Business Studies, Vol.XXVII, No.2, December 2007

Mihir Kumar Roy, Sk.Kamrul Hassan, M.M. Bhuiyan, "Online Banking in Bangladesh An Empirical Analysis", ASA University Review, Vol. 5 No. 2, JulyDecember, 2011

Nitai Chandra Debnath, Abdullah Al Mahmud, The Environment of E-Commerce in Bangladesh Daffodil International University Journal of Business and Economics, Vol. 2, No. 2, July 2007

Rahman, Habibur, Nasir Uddin, Syed Ahmed Siddiqui, "Problems and Prospects of E-Banking in Bangladesh", International Journal of Scientific and Research Publications, Volume 2, Issue 7, 1 ISSN 2250-3153, July 2012.

Razibul Hasan, M Abdus Sobhan, "Study on e-Commerce Threats and Security" National Conference on Communication and Information Security (NCCIS 2012) Daffodil International University, Dhaka, Bangladesh, 31 March 2012.

Sazzad A. B. M. R., Alam S. B., Sakib N., Shahanaz C. and Fattah S. A., "Secured Cellular Banking Protocols Using Virtual Internet with Digital Watermarking" IEEE Xplorer, 978-1-4244-9991-5/11, 2011.

Shifeng L. and Rong C., "Wireless E-commerce Payment and its Development in China", International Conference of Information Science and Management Engineering, pp. 554-558, 2010. 
Singh Sh., "An Empirical Investigation of the Determinants of Users Acceptance of E-Banking in Singapore (A Technology Acceptance Model)" International Journal of Management Business Research., 2 (1), pp.69- 84, Winter 2012.

Sohel Ahmed, Shah Johir Rayhan, Md. Ariful Islam, Samina Mahjabin, "Problems and Prospects of Mobile Banking in Bangladesh", Journal of Information Engineering and
Applications, ISSN 2224-5758 (print) ISSN 2224-896X (online) Vol 1, No.6, pp 16-35, 2011.

Yang Jing, On-line Payment and Security of E-commerce", Proceedings of the 2009 International Symposium on Web Information Systems and Applications (WISA'09) Nanchang, P. R. China, May 22-24, 2009, pp. 046-050

$--0-$ 